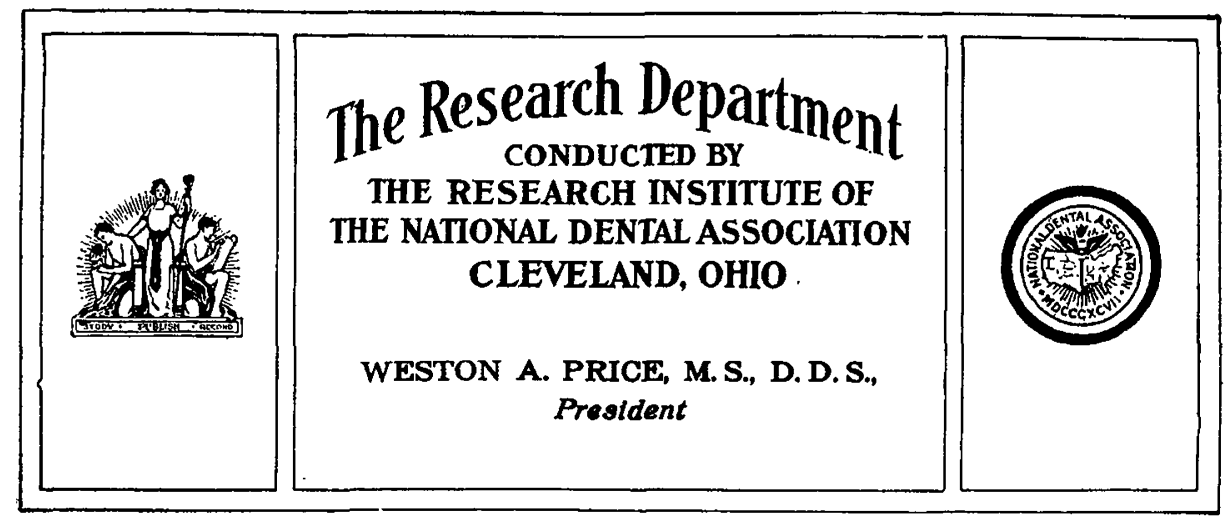

\title{
LIBERATION OF ANTIBODIES ON INJECTION OF FOREIGN PROTEINS.
}

\author{
By Siegfried F. Herrmann, Minneapolis, Minn.
}

(Researches Conducted Under the Auspices of the University of Minnesota and the Research Institute of the National Dental Association.)

$\mathrm{M}$ ANY reports have been published concerning the treatment of acute and chronic infections by the intravenous injection of foreign proteins. This treatment has been applied to typhoid fever, arthritis, and certain skin diseases. It apparently developed as an outgrowth of the injection of vaccines. Vaccine therapy, once the great hope of modern therapeutics, failed to produce the promised results, and, with the exception of prophylactic vaccination against typhoid, variola, rabies, and perhaps in acne and allied pyogenic skin diseases, was being abandoned more and more. Now there is an apparent revival of allied therapeutic methods in the form of foreign protein injections.

The beginning of foreign protein therapy dates back to the work of Fraenkel ${ }^{1}$

1Deutsch. med. Wchnschr., 1893, 19, p. 985.

Reprint from The Journal of Infectious Diseases, vol. 23 , No. 5 , Nov., 1918 , pp. $451=469$. in 1893 , who treated 57 cases of typhoid fever with subcutaneous injections of typhoid vaccine. He reported that most of the cases were favorably modified, and that a few terminated by rapid lysis. This use of typhoid vaccine during the active, acute stage of the disease was a new departure, which demanded further investigation.

Rumpf, ${ }^{2}$ using a vaccine of Bacillus pyocyaneus, repeated the work in another group of cases, and observed equally favorable results.

Ichikawa, ${ }^{3}$ using intravenous injections of sensitized vaccine, and Kraus and Mazza, using polyvalent vaccine, were able to produce favorable modifications in $60 \%$ of their cases. They also observed equally good results in paratyphoid and found that colon vaccine could be substituted for the typhoid vaccine.

More recent work on typhoid has been reported by Lüdke ${ }^{5}$ with albumoses;

2Ibid., 1893, 19, p. 987.

${ }^{3}$ Ztschr. f. Immunitätsforsch. u. exper. Therap., $1914,0 ., 23$, p. 32.

${ }^{4}$ Deutsch. med. Wchnschr., 1914, 40, p. 1556.

${ }^{6}$ München. med. Wchnschr., 1915, 62, p. 321. 
Saxl, using a solution of caffein and camphor; Kibler and McBride, using typhoid vaccine, etc.

Foreign protein has been used also in the treatment of arthritis. Notable is the report of Miller and Lusk. ${ }^{8}$ Miller later summarizes his results and gives an extensive bibliography of work done by other clinicians. ${ }^{9}$ The results as reported appear promising, especially in acute arthritis.

Other favorable results have been reported in skin diseases, puerperal sepsis, conjunctivitis, iritis, trachoma, typhus, tuberculosis, etc. Among the variety of proteins employed are: colon vaccine, chicken serum, whole blood, proteose, albumose horse serum, and autolyzed vaccine.

Closely related to the response to foreign protein is the old and familiar observation that a specific disease may sometimes improve with the advent of some intercurrent infection. For example, the symptoms of acute gonorrhea have been observed to subside with the incidence of typhoid fever. Attention has also been called to the increased resistance of the body to various common infections, following any vaccine injection.

It is evident that foreign protein therapy is empirical and non-specific. Almost any foreign protein seems to be effective, and may be employed more or less successfully, under suitable conditions, in a variety of diseases. The question arises as to what factor is responsible for the apparent benefits observed. If this manner of treatment is to be placed on a scientific basis this factor must be determined. Clinical investigations have thrown no light on this question. The type of reaction is apparently the same in all cases.

As described by Kibler and McBride ${ }^{7}$ the reaction of a typhoid patient to the intravenous injection of typhoid vaccine is as follows:

1. Temperature.-Within a few minutes to 1 hour after the injection a chill occurs, lasting 20-30 minutes. This is followed by a rapid rise of temperature which later falls abruptly, and then

'Wiener med. Wehnschr., 1916, 66, p. 115.

TJour. Infect. Dis., 1917, 21, p. 13.

Jour. $\Delta \mathrm{m}$. Med. Assn., 1916, 66, p. 1756 and 1916,67, p. 2010.

'Miller: Jour. Am. Med. Assn., 1817, 69, 765. tends to remain remittent in favorable cases.

2. Leukocytes.-Usually there is an early leukopenia within 4 hours, due mainly to a disappearance of polymorphonuclears. Within about 12 hours this is followed by a moderate polymorphonuclear leukocytosis.

3. Blood pressure is usually decreased by $10-15 \mathrm{~mm}$. after the chill.

4. Coagulation Time--Only slight and insignificant changes have been observed.

5. Antibodies.-No essential difference from the specific response to the injection of typhoid antigen in a normal individual was observed in these typhoid patients. It is to be noted, however, that conditions here differ somewhat from those in which an heterologous protein is injected.

The reaction in arthritis cases agrees essentially in the first four particulars with the reaction in typhoid fever. The antibody response will be considered later. Most clinicians seem agreed in regarding the severe chill as the most important factor in this reaction. It is evident that a chill alone cannot be responsible for the marked relief from pain and for the remission in the course of an acute arthritis. It is possible, however, that the resulting hyperpyrexia may have an effect in favoring immune reactions and antibody production.

Rolly and Meltzer, ${ }^{10}$ in a study on the effect of high temperatures, injected a series of rabbits with small doses of typhoid bacilli or cholera vibrios. Some of these rabbits were kept in an oven so that their body temperature remained between 40 and $42 \mathrm{C}$. The controls were kept at ordinary room temperature. They observed a higher average production of agglutinins and lysins in the high temperature rabbits than in the controls. They also showed that phagocytosis by human leukocytes in vitro occurs at its optimum between 37 and $40 \mathrm{C}$.

More recently, Winslow, Miller and Noble $^{11}$ investigated the effect of moderately high temperatures on the production of lysins against sheep blood corpuscles. They kept their rabbits in an oven at a moderately high temperature, 29 to $32 \mathrm{C}$. Injections of sheep cells were given and the hemolytic titer estimated each week. They found that

\footnotetext{
${ }^{10}$ Deutsch. Arch. f. klin. Med., 1908, 94, p. 335. ${ }^{11}$ Proc. Soc. Exper. Biol. and Med., 1916, 13,
} 
the rate of lysin production in the heated rabbits was slower than that in the controls.

These experiments may indicate that a moderately high temperature lowers the general vital resistance to a beginning infection. Once an infection is established, however, according to Rolly and Meltzer's results, hyperpyrexia may bring about a greater production of antibodies.

If a specific leukocytosis could be observed, one might think that this would be a factor in overcoming the infection, but the degree of leukocytosis seems only to parallel the severity in each case. ${ }^{12}$ Gay and Claypole ${ }^{18}$ believed that a specific hyperleukocytosis occurred in typhoid immune rabbits, following injections of typhoid bacilli, but McWilliams ${ }^{34}$ later showed that both normal and immune rabbits respond to about the same degree. The leukocytosis therefore cannot be regarded as specific.

The slight variations in blood pressure and coagulation time are evidently insignificant.

We pass now to a consideration of the. antibody response. Very little work on this aspect of the question has been done, yet it seems as if the explanation of a therapeutic response, in the case of any infection, to the injection of a substance not specifically bactericidal to the infecting organism, should logically be sought in the liberation of specific antibodies against that organism. Ordinarily when the body overcomes a streptococcic infection, for example, we believe this is accomplished by the production of antibodies against the streptococcus. Why, then,. should we not suspect that the therapeutic effect of foreign protein injections in infections, obviously not due to the foreign protein per se, has as its basis the liberation of specific antibodies against the causative organism? In the case of arthritis we believe that the symptoms persist because the antibodies which should normally be produced are for some reason not liberated.

In the light of Ehrlich's receptor the-

${ }^{12}$ Cross : Journal-Lancet, 1917, 37, p. 764.

${ }^{18}$ Arch. Int. Med., 1914, 14, p. 662.

14Jour. Immunol., 1916, I, p. 159. ory, we recognize three distinct phases in the production of antibodies: (1) the sensitization of the tissue cells; (2) an overproduction of sessile receptors; (3) the liberation of these receptors from the cells. A perfect antigen is one which causes all of these phases to be completed. It seems a plausible hypothesis that in those cases of arthritis, etc., which show a rapid therapeutic response to injections of foreign protein, the etiologic organism is acting only as an imperfect antigen. It sensitizes the cells and causes sessile receptor production, but does not give the necessary stimulus to cause these receptors to be thrown off. The foreign protein then supplies this stimulus, the system is flooded with specific antibodies, and a remission of the infection results. Altho a variety of proteins may serve to complete this second phase, the reaction is still absolutely specific, since there must be a specific stimulation of cells, and a final liberation of specific antibodies.

In this connection I would recall the experiments of Bruck. ${ }^{15}$ According to Ehrlich's theory a molecule of tetanus toxin is composed of a haptophore group, which unites with the cell receptor, and a toxophore group, which is responsible for the poisoning of the cell. This toxophore group can be destroyed by various methods such as heat, light and long preservation. The toxin has then become a toxoid. The haptophore group can still unite with a sessile cell receptor, or with a specific antibody, but because of the absence of the toxophore group the molecule has become innocuous. Bruck injected rabbits with small repeated doses of such a toxoid. The rabbits were found to produce very little, or no free antitoxin, the amount being dependent on the amount of effective toxophore groups which still remained in the toxoid. He further showed that rabbits injected with tetanus toxoid, during the first few succeeding hours possessed a greater tolerance for tetanus toxin, but that later they showed an. actual hypersensitiveness, being killed by only a fractional portion of the ordinary lethal dose of toxin.

15Ztschr. f. Fyg. u. Infections-Krankh., 1904, 46, p. $176 ; 48$, p. 113 . 
These results Bruck interpreted as follows: The haptophore group of the toxoid at first is anchored to the specific cell receptor. The toxin molecule introduced soon afterward, therefore, cannot reach the cell, since all the receptors are blocked. Later, however, an overproduction of sessile receptors occurs, and a hypersensitiveness to toxin results, since the avenues of approach to the cell are increased many times. The toxoid has acted as an inferior antigen. It has brought about the first and second steps of antibody production, namely, (1) sensitization of cell receptors, and (2) the overproduction of similar sessile receptors, but it has lacked the necessary stimulus to cause the discharge of these receptors. Had the rabbits been immunized with small doses of unchanged toxin this third stage would have been completed. Bruck therefore sees in the toxophore group the necessary stimulus for the setting free of the receptors. Might not a foreign protein, in an analogous way, supply such a stimulus? It was with this hypothesis in view that I undertook an investigation of the effect of foreign protein on antibody production. The experiments have been conducted entirely with rabbits, because all the factors can thus be much more accurately controlled than in a purely clinical investigation.

Several other investigations have been reported which touch on the immune reactions in foreign protein therapy.

Jobling and Petersen" report a "mobilization of ferments," notably protease and lipase, following foreign protein injections. Later ${ }^{17}$ they point out an "increase in antiferment," dependent on "highly dispersed, unsaturated lipoids," and conclude that "the main therapeutic factor is probably an increased dispersion of colloids."

Culver ${ }^{18}$ investigated the opsonin and lysin content in the serum of patients with gonorrheal arthritis, after intravenous injections of gonococcic vaccine and proteose. He reports a rise in titer of these antibodies.

Bull ${ }^{19}$ reports a rise in the antibodies of typhoid immune rabbits after the injection of typhoid bacilli; but his re-

\footnotetext{
${ }^{16}$ Jour. Am. Med. Assn., 1915, 65, p. 515.

${ }^{17}$ Ibid., 1916, 66, p. 1753.

${ }^{18} \mathrm{Jour}$. Lab. and Clin. Med., 1917, 3, p. 11

${ }^{10}$ Jour. Exper. Med., 1916, 23, p. 419.
}

sults could not be confirmed by Teague and McWilliams, ${ }^{20}$ who suggest a new theory to explain the therapeutic effect on cases of typhoid, of intravenous injections of typhoid vaccine. On the supposition that blood serum is more bactericidal than lymph, they base the theory that the vaccine causes a greater flow of bactericidal serum into the lymphoid organs, and thus overcomes the local infection. It does not appear that this theory has been substantiated.

On the basis of the hypothesis that the foreign protein reaction serves as a stimulus to set free specific antibodies, I first investigated opsonins, for the streptococcus. This organism is notably a poor antigen, in that it is difficult to obtain a high antibody titer against it. An animal sensitized with this organism should therefore be a favorable subject for the liberation of anti-bodies by foreign protein.

Series 1.-Two rabbits were injected - intravenously at 3 -day intervals with 1 c $\mathrm{c}$ of a fresh suspension of killed streptococcus viridans. The organism was grown on blood agar slants, and a 24-hour growth washed off with $10 \mathrm{c}$ c salt solution. This emulsion was heated at $60 \mathrm{C}$. for 1 hour to kill the bacteria, and $1 \mathrm{c} c$ of this vaccine used as a dose. A fresh vaccine was made each time. The fourth injection consisted of $1 / 2 \mathrm{c} c$ of living streptococci. Five days later the opsonic index was determined, and $2 \mathrm{c}$ c of human ascitic fluid injected intravenously.

The method of determining the opsonic index was that of Wright, using the experimenter's own leukocytes and serum as a standard.

Both rabbits were found to have a very low opsonic index 5 days after the fourth injection of streptococci; $2 \mathrm{c} c$ of human ascitic fluid were then injected, and a marked rapid rise of opsonins occurred, the total increase being $700 \%$ in 48 hours. Apparently the foreign protein acted as an effective stimulus to liberate sessile receptors.

After 18 days the opsonic content was again found to be at a low level. Two further injections of streptococci were then given. This time an interesting variation in response occurred. The opsonic index of Rabbit 17 rose, while that of Rabbit 311 continued to fall. In the former the streptococci evidently acted

\footnotetext{
${ }^{20}$ Jour. Immunol., 1917, 2, p. 185.
} 
as a perfect antigen, causing all three stages of antibody production, while in the latter the final liberation of antibodies did not take place. This supposition was confirmed by the effect of an injection of ascitic fluid. In Rabbit 17 there stimulus to cause the cells to throw off these receptors.

Series 2.-In this series 2 rabbits were injected with fresh suspensions of meningococci, and human serum was used as foreign protein. Rabbit 395 received 2

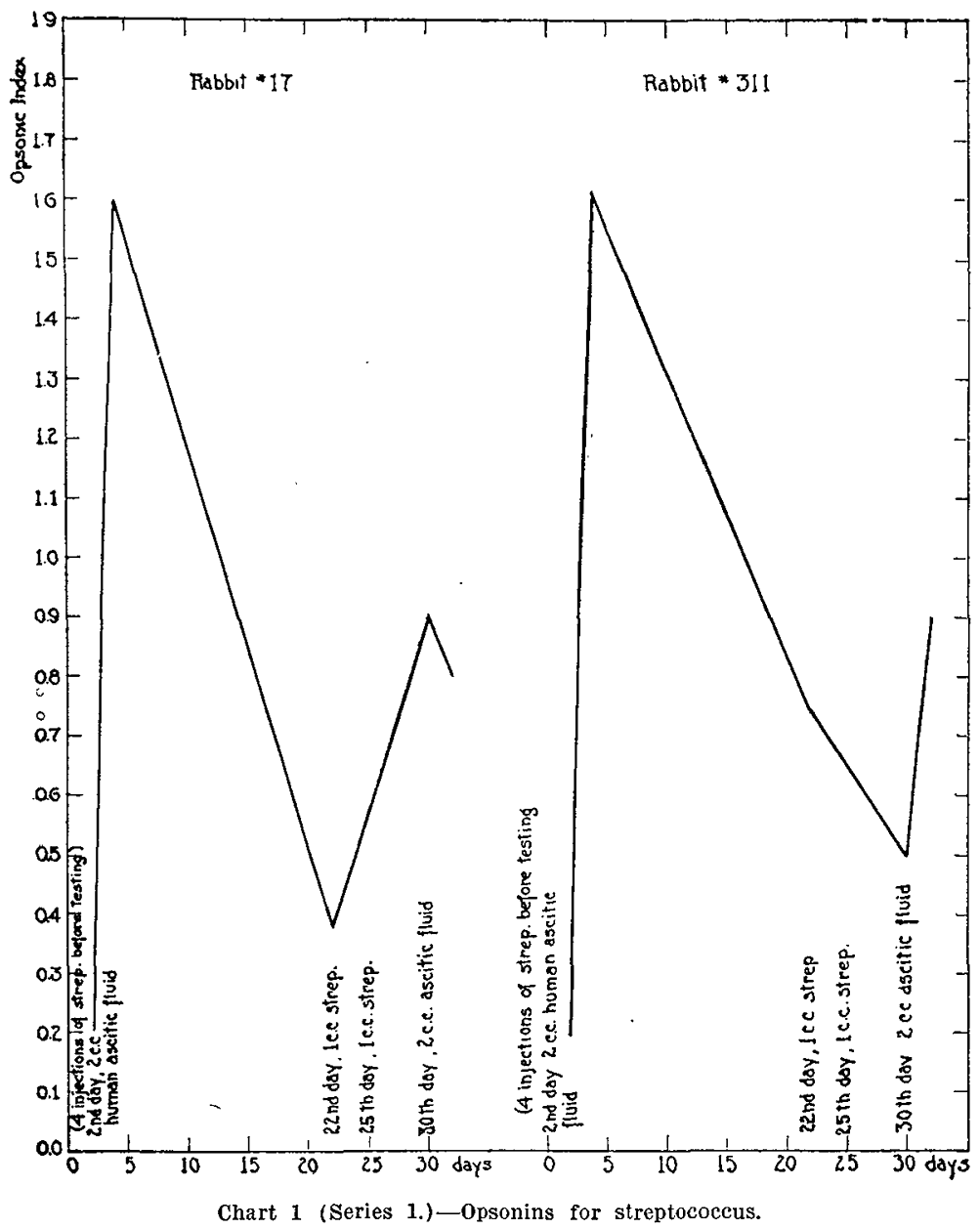

resulted no further increase in opsonins. The stimulus of the antigen had been sufficient to liberate all antibodies. In Rabbit 311 a rapid liberation of opsonins followed the foreign protein injection. In this case we picture the tissue cells as loaded with an overproduction of specific sessile receptors. The foreign protein reaction then acted as an effective injections of serum with a resulting rise after each injection. Apparently the cells were not completely desensitized by the first serum injection. Rabbit 268 received no second injection and showed a gradual decrease in opsonins.

In order to demonstrate whether theise antibodies were specific for meningococci, and also as a control of the technic, the 
serums were also tested each time for opsonins against $B$. typhosus. The typhoid opsonic index remained low and unchanged thruout.

Series. 3.-Two rabbits were given 4 day following, while the opsonic index of the latter remained stationary. The control test for $B$. typhosus remained unchanged in both cases.

During the next 40 days 4 injections of

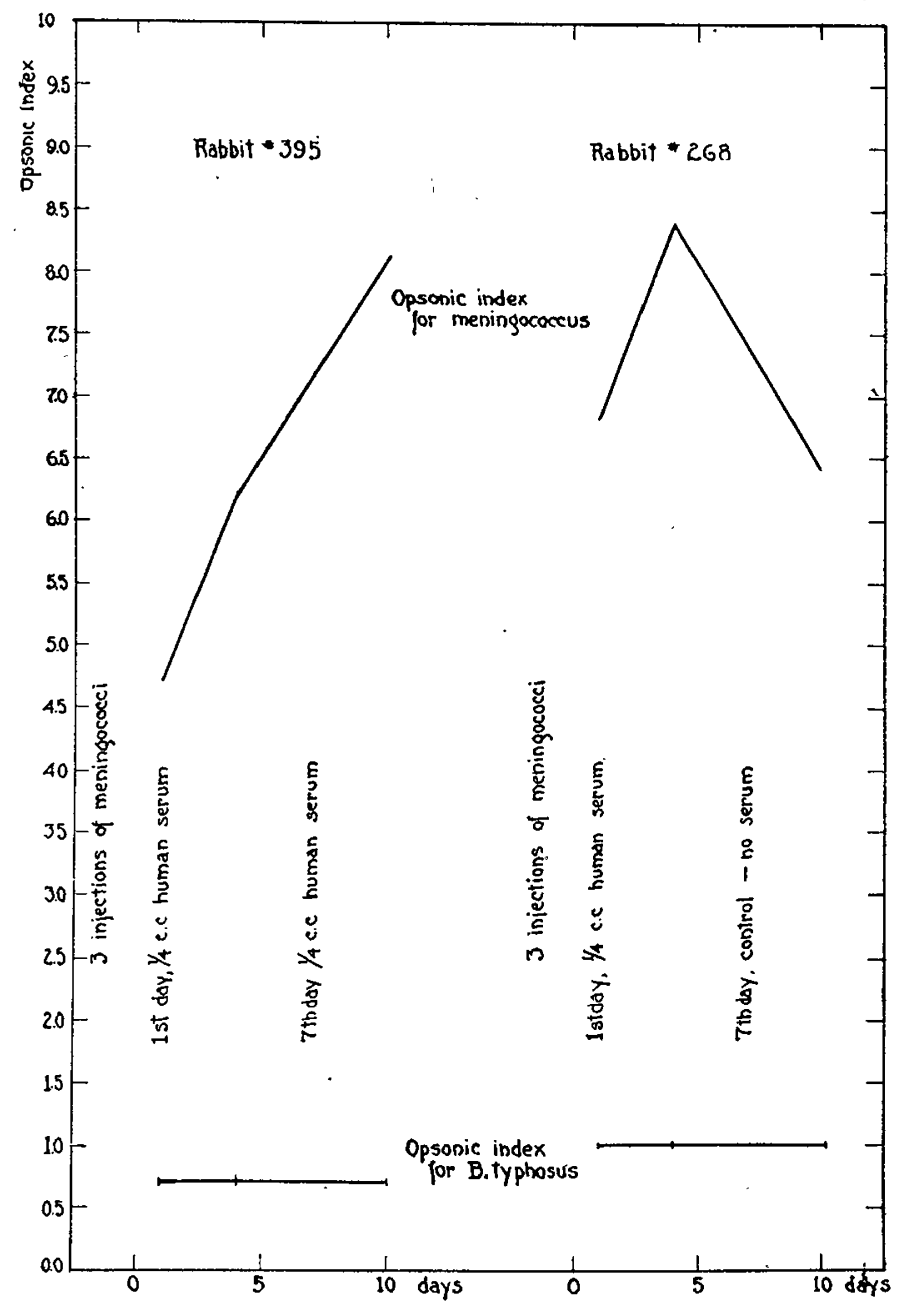

Chart 2 (Series 2.)-opsonịns for meningococcus.

intravenous injections of $\mathbf{S}$. viridans at 3-day intervals, as in Series 1. Six days after the fourth injection the opsonic index was determined. Rabbit 31 then received 1 c c of human serum intravenously, while Rabbit 32 was used as a control and received no serum. The former showed a rise of $38 \%$ on the third a dextrose broth culture of streptococcus were given. Six days after the last injection the opsonic index was again determined. It was found lowered in both rabbits. Rabbit 32 then received 1 c c of human serum. There followed a rise of nearly $300 \%$. Rabbit 31 showed a spontaneous rise, but to a much less 
degree. A check opsonic determination for meningococci showed no variation.

It was now thought that if an increase in opsonins occurred, following foreign protein injection, it should also be possible to demonstrate a simultaneous rise in the agglutinin titer for streptococci. platinum loop, 1 drop each of diluted serum and of a 15-hour dextrose-broth culture of streptococcus. The coverslips were then inverted on vaselined hollow ground slides, and left at room temperature. Readings were then taken under the microscope at the end of 3 hours. Posi-

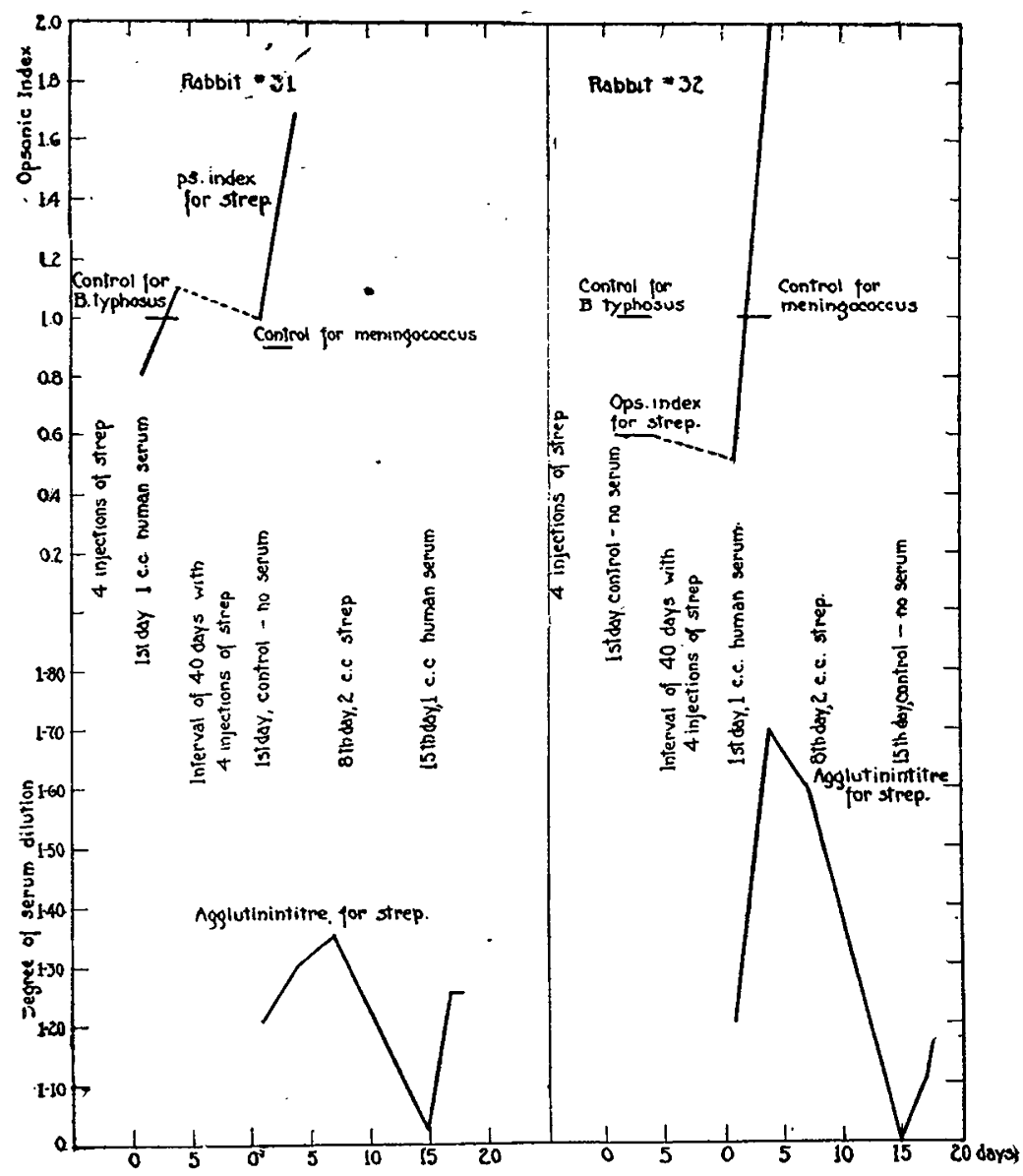

Chart 3 (Series 3.)-Opsonins and agglutinins for streptococcus.

The agglutinin titer was determined by the microscopic method as follows: The rabbits were bled from the ear veins, the blood allowed to clot, and the serum separated by means of rapid centrifuging. Varying dilutions of the serum were then made in $0.9 \%$ salt solution. Hanging drop preparations were made by placing on a coverslip, with a small tive agglutination could be observed in the lower dilution, consisting of definite clumping of the streptococcal chains. The highest degree of dilution in which a positive test occurred was recorded as the agglutinin titer.

The first tests were made simultaneously with the last opsonic determinations. In response to the first serum in- 
jection Rabbit 32 showed a rise in agglutinin titer of $250 \%$. Rabbit 31 , which served as a control at this time, also showed a slight rise $(50 \%)$ and continued to rise gradually. The agglutinin
Seven days later the agglutinin titer had fallen very low in both rabbits. This time Rabbit 31 received 1 c c of human serum, while Rabbit 32 served as control. A rapid rise of agglutinin titer occurred

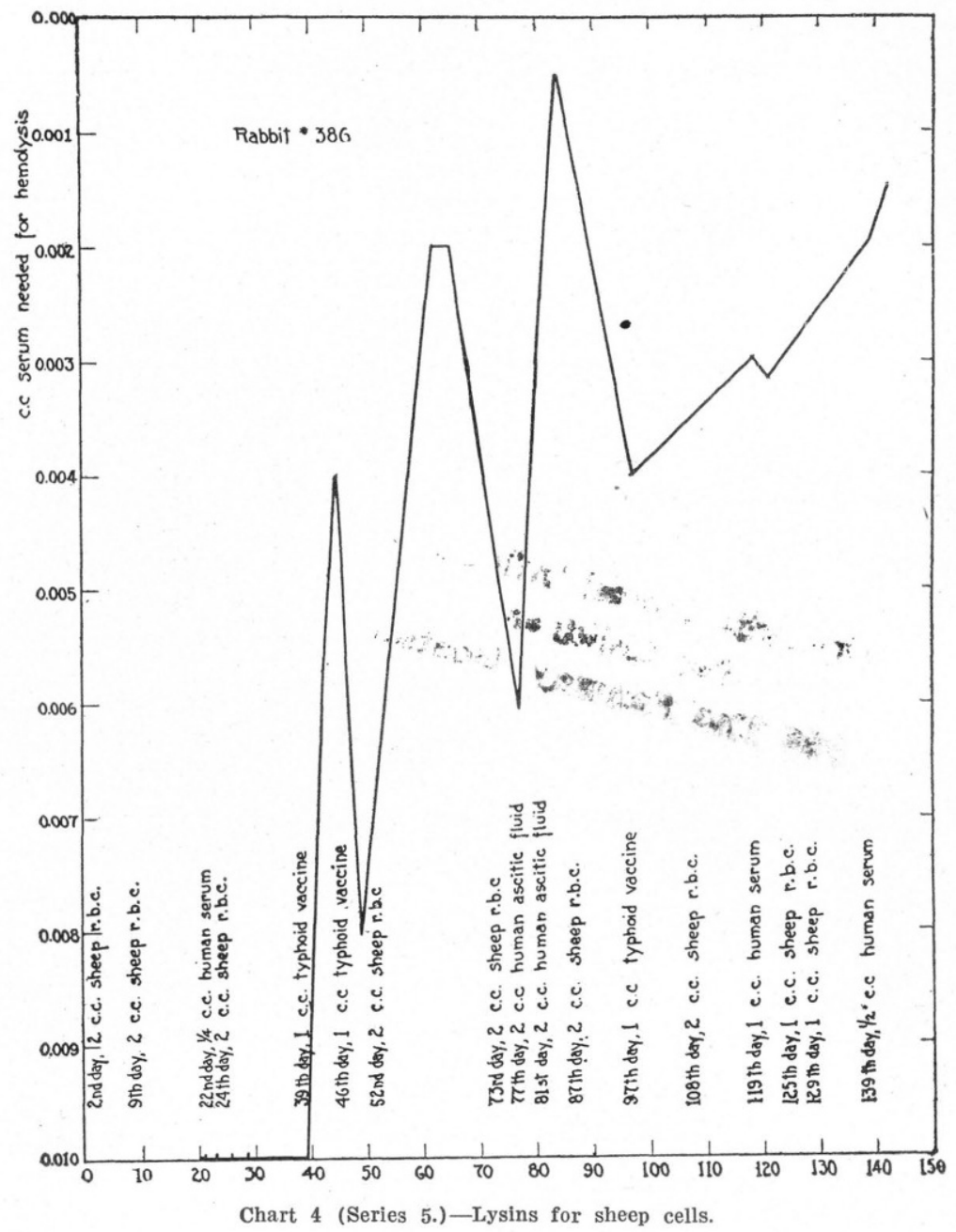

titer of Rabbit 32 began to fall after the third day. All the sessile receptors apparently had been freed by the foreign protein injection, while in Rabbit 31, without the stimulus of foreign, protein, they were liberated to a less degree and more slowly.

In order to resensitize the tissue cells $2 \mathrm{c}$ c of broth culture were now injected. in the former which then remained stationary. In the control rabbit a more gradual rise occurred. Thus the specific response to the foreign protein injection was again observed.

Series 4.- It now became necessary to investigate whether or not foreign protein injections would serve to bring about a mobilization of anti-bodies against an 
organism which was known to be a good antigen, that is, one which when injected into an animal, would readily cause the production of a high titer of free antibodies. The typhoid bacillus is known to be such a perfect antigen, when injected into rabbits. Indeed, it is not unusual to obtain an agglutinin titer against typhoid as high as 1:500,000 dilution.

Two rabbits were injected repeatedly with emulsions of typhoid bacilli, until they showed an agglutinin titer of 1:50, on testing by the macroscopic method; 1 c c of guinea-pig serum was then injected and the agglutinin titer again determined in 48 and 72 hours. No rise in titer was apparent.

Further injections of typhoid bacilli were then given until the agglutinin titer reached 1:100. Then $1 / 2 \mathrm{c} \quad \mathrm{c}$ of human serum was injected. Again no increase in agglutinins could be observed during the next 72 hours. A second injection of human serum did not changet the titer.

In order to check these abditive ro sults 2 more rabing im with typhoid Watell. Aftor 2 injections of bacilli the agglutinin titen was fornd to be zero, by the mieroscople hanging drop method, asedescribed under Series $3 ; 1 / 2 \mathrm{c} c$ of human serum was then injected, and the antibody titer again determined on the third day following. Again no agglutinins were found. Evidently the rabbits had not yet been sufficiently sensitized against the bacilli.

Immunization with typhoid bacilli was then continued until the microscopic method revealed an agglutinin titer of 1:3,000. Two c c of human ascitic fluid were then injected intravenously. No rise in agglutinin content resulted.

The serum of these rabbits was also tested for complement fixing bodies, with the idea in mind that the foreign protein reaction might possibly bring about a liberation of such antibodies, altho it apparently had no effect on the agglutinin content.

As an antigen in the complement fixation test an old suspension of typhoid bacilli in salt solution, to which $0.3 \%$ tricresol had been added, was used. The test was carried out with the usual technic, using this typhoid antigen, washed sheep blood cells, fresh guinea-pig complement, and rabbit amboceptor. The serum of the typhoid immune rabbits was inactivated by heating at $56 \mathrm{C}$. for $1 / 2$ hour, then diluted, and the fixing power of a given quantity tested. It was found that the ability of the inactivated serum to fix complement was not changed in the slightest degree by foreign protein injections.

We must conclude that foreign protein injections have no effect on the antibody production in typhoid immune rabbits. The typhoid bacillus in apparently a perfect antigen in rabbits, and no foreign protein is needed to stimulate the liberation of antibodies against it.

How, then, can we reconcile this with the apparent therapeutic benefits observed in some human patients? May it not be possible that some patients do not react completely to the antigenic stimulation of the typhoid bacillus? In such cases the foreign protein might well serve as a stimulus causing the sensitized cells to throw off their sessile receptors. This sudden flooding of the system with antibodias might then be responsible for the neatission in the disease. This hypothesis seems to be supported by the succeeding series.

ร์ซies 5.-Thus far I have recorded 8 bservations on opsonins and agglutinins. It seemed desirable also to investigate the response of a third type of antibodies, lysins, to foreign protein injections. Since it is difficult to make accurate determinations of the lysin content of a serum for a specific bacterial cell, we decided to use as our antigen, washed sheep corpuscles. A hemolytic titer can be very accurately obtained, while a bacteriolytic titer, obtained by the method of extinction and plating, is modified by too many possible errors of technic.

It is well known that rabbits will readily produce lysins against sheep corpuscles. Common use is made of this fact in producing amboceptor for the hemolytic system of the Wassermann reaction. We may say, therefore, that sheep cells act as a good antigen when injected into rabbits. This would allow us to predict, on the basis of the preceding series, that foreign protein injection into rabbits sensitized against sheep cells would have little effect on the liberation of specific lysins. It has, however, been frequently observed in this laboratory that a great variation exists in the readiness with which different rabbits will produce amboceptor when injected with sheep cells. Rubinstein ${ }^{21}$ recently studied the hemolytic titer of rabbits after 3

${ }^{21}$ Campt. rend. Soc. de biol., 1917, 80, p. 908. 
injections of sheep red cells. The titer was determined before each injection, and 7 days after the third. He found that of 11 rabbits only 8 showed a definite marked rise in lysins after each injection. In one of the remaining 3 the titer remained the same, and in the other 2 there was even a decrease in lysin con- corpuscles, $1.5 \mathrm{c}$ c of $0.9 \%$ salt solution, and graduated amounts of inactivated rabbit serum. The least amount of serum that would cause complete hemoly. sis after incubation at $37 \mathrm{C}$. for 1 hour was recorded as the lysin titer.

A total of 20 rabbits was used in this series. The rabbits were injected in-

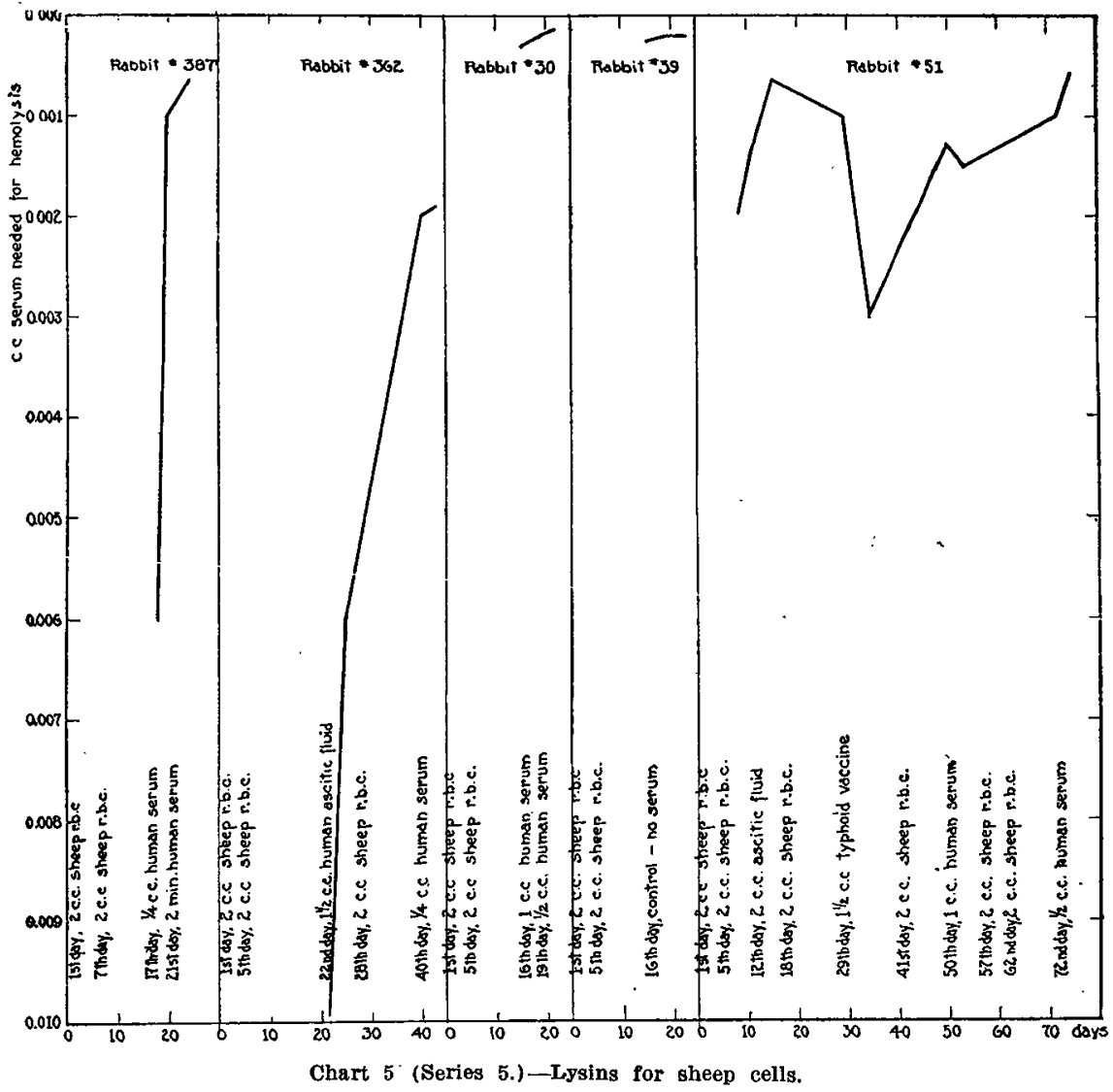

tent after successive injections. In such rabbits as the latter 3 the sheep cells evidently acted only as an inferior antigen, and in such cases we would expect, on the basis of our previous work, to be able to liberate antibodies by means of foreign protein injections.

The hemolytic system in these experiments consisted of $0.10 \mathrm{c} c$ fresh guineapig complement (diluted 1:10), $0.5 \mathrm{c}$ c of a $2 \%$ suspension of fresh washed sheep travenously with 2 initial doses of sheep corpuscles in salt solution. As a rule the lysin content was then measured, 10-12 days after the last injection, it having been determined that the lysin titer normally reaches its height by the end of this period. After foreign protein injections, either human serum or typhoid vaccine, the lysin content was again determined, usually in 72 hours, in order to give ample time for any resulting change in titer to take place. 
In Rabbit 386 sheep cells evidently acted as an inferior antigen, the lysin content 11 days after the second injection being very low and remaining so; $0.25 \mathrm{c} c$ of human serum injected on the 17th day after the last injection did not influence the lysin content. Believing that this was due to the fact that the tissue cells were no longer properly sensitized, another injection of sheep cells was given. Eleven days after this the titer was still at the same low level. An injection of foreign protein (typhoid vaccine) was then given, and an immediate marked liberation of lysins occurred. These antibodies disappeared rapidly. A second injection of typhoid vaccine in 7 days had no effect on raising the lysin titer, but the curve continued to fall rapidly. A third injection of red cells was then given and this time acted as a perfect antigen. The lysin content rose to its height in 10 days and remained high for several days. After it began to decrease another injection of red cells was given, but this time an injection of ascitic fluid was given only 4 days later, in order to determine whether an early stimulation by foreign protein would serve to liberate antibodies. A very pronounced mobilization of lysins followed.

This alternating introduction of red cells and foreign protein was continued. Everytime the mere injection of antigen (red cells) failed to produce lysins in the rabbit serum a mobilization of these antibodies could be effected by foreign protein. When, on the other hand, there was a normal response to the antigen, the foreign protein was followed by no further liberation of Iysins. After the last 2 injections of red cells apparently all the receptors were not spontaneously liber. ated because there was a slight response to foreign protein 10 days later.

Rabbits 387 and 362 were of the same type, as they failed to respond to injections of red cells by a proper production of antibodies, but when then injected with foreign protein a marked liberation of lysins occurred.

Rabbits 30 and 39 responded very well to the antigenic stimulation of sheep cells; Rabbit 39 was used as a control while Rabbit 30 received human serum on the 11th day following the last injection of antigen. No marked difference was noted in the reactions of the $2 \mathrm{rab}-$ bits. This was observed also in a number of other cases. When the titer is already high, foreign protein will not bring about a further rise in antibody content.

Rabbit 51 represents a negative result which cannot be readily explained. The typhoid vaccine injected on the 29th day should have been followed by a rise in antibodies, according to our other observations, since the red cells 11 days earlier had not produced a liberation of lysins. In other respects, however, this curve is in accord with the general results.

\section{SUMmaRy.}

In rabbits sensitized with streptococci a definite liberation of specific opsonins and agglutinins follows the injection of foreign protein.

A similar rise in specific opsonins also occurs in rabbits sensitized with meningococci.

Foreign protein injections have no effect on antibodies in typhoid immune rabbits.

In suitable rabbits, which do not readily produce lysins against sheep corpuscles, the injection of foreign protein within 10 days after the injection of antigen is followed by a marked liberation of specific lysins.

A variety of foreign proteins can be used. Human serum, typhoid vaccine, human ascitic fluid, and guinea-pig serum proved equally efficacious.

\section{CONCliUsion.}

The intravenous injection of foreign protein serves as a stimulus for the liberation of specific antibodies in animals in which the previously injected antigen is unable to cause such a liberation. This insufficiency may lie either in the antigen or in the rabbit. 